Vol. 4, No. 2, 2017

https://doi.org/10.23939/eem2017.02.037

UDC 339.138

I. Ugolkov

$\mathrm{PhD}$ student

O. Karyy

Doctor of Economic Sciences, Associate Professor,

Lviv Polytechnic National University

\title{
THE CHOICE OF LANGUAGES FOR WEBSITE OF ORGANIZATIONS IN CASE OF MULTILINGUAL CUSTOMERS
}

\begin{abstract}
The paper describes the changes of potential customers' language priorities in multilingual societies at the example of Ukraine. The case of Ukraine is interesting because of sharp changes in customers' attitude to other countries. It makes huge influence on customer behavior while buying goods: customers pay much more attention on the country of product origin. That is why the hypothesis of the article was that such changes in attitude to products produced in certain countries also connected with changes in attitude to languages of these countries and that companies should take into account these changes in their internetmarketing. To check this hypothesis the survey to identify business attitude to this question on the example of websites of Ukrainian bank sector was made. This economic sector is the most vulnerable to customer loyalty. Research showed that Ukrainian language is the prior to satisfy potential clients, and Russian language is needed to avoid the incomprehension of Russian speaking population.
\end{abstract}

Keywords: internet-marketing, search engine optimization, multilingualism, customer behavior, banks.

General formulation of the problem. Due to the military and political conflict in Eastern Ukraine behavioral characteristics of ordinary customers and users of Internet resources are recently changing. In this situation there is the question that arises in the minds of business owners and web marketing specialists: what is the impact of using different languages in their websites? As we know, the population of Ukraine consists of several ethnic groups including Ukrainians, Russians, Jews, Poles and other nationalities. At the same time the usage of many languages on web sites is difficult technically and requires a lot of additional expenses. That's why there is a logical question: which languages we must choose to use on websites?

Relevance of the chosen topic. The problem of multilingualism is highlighted in Ukrainian society due to the conflict with Russian federation but poorly taken into account in functioning of Internet resources of enterprises.

Analysis of recent studies and publications. There are many authors that made researches of multilingual phenomenon in modern Ukrainian society. For example, in [1] it is indicated that today informational websites are often bilingual, but Ukrainian version is usually secondary and low quality because texts are translated using webtranslators without correcting any basic mistakes Most websites of Ukrainian enterprises don't have Ukrainian version and even if they have it, Ukrainian version is usually placed on the second place after Russian, demonstrating the attitude of business to the use of Ukrainian language. Without knowing and using Russian language it will be difficult to find a work because most of job vacancies are created by using this language. Also without knowing Russian language it will be hard to buy something in online-shops, the owners of which often don't mind to create product descriptions using official state language. 


\section{Ugolkov, O. Karyy}

Enough common phenomenon for websites that are oriented on Eastern and South Ukraine is the use of only Russian language. It is relied to the particularity called asymmetrical bilingualism. That means that most people that speak Ukrainian speak Russian as well, but at the same time not all people that speak Russian speak Ukrainian. Similar trends exist in Estonia. Due to the residence of a large number of Russian-speaking persons there are many websites that are translated on Russian language. In the internet you can find Russian version of presidents' website http://www.president.ee/ru, http://www.eesti.ee/rus (national website); they have bilingual website of fiscal and customs department, police department, border security department, department of national medical security, state court, some regions, cities, politician parties, organizations. Russian version of websites is used also in many Estonian newspapers and magazines [3]. A completely different situation is observed in Latvia. The law about national language of this country force legal entities to provide official information on Latvian and this fact limits the use of Russian language in the country [4].

The problem of multilingual customers and business rises not only on post-soviet space but also in other countries that have similar ethnic situation. This problem is explored by R. Miller [5] in his article about the reaction of Canadian business on the spread of French language. He speaks about infringement of consumers' rights who lives in French-speaking region Quebec by the ordinary manufacturers who orients on general trends and don't take into account the needs of French-speaking population. The author proposes the implementation of national constraints and incentive measures which will help the future spread of French language in a country. He indicates that on political, social and legal level regional authority must build clear strategy of the French language support.

Speaking about Ukraine, O. Kramar [6] shows the statistics in his researches. He indicates that the amount of national content made in Ukraine in 2011 was not significant among all content that circulated in Ukrainian Internet. He thinks that its part was not more that $6-10 \%$. It should be underlined that the statistics used by author (bigmir.net) has strong pro-Russian orientation. Author also provides statistics about languages of websites in 2003, 2007 and its interpretation that is in some points questionable. In the first case for 2003 author analyze all websites but for 2007 he uses the statistics of the most popular websites of Ukrainian Internet. The fact is that the popular websites want to minimize their risks and demonstrates the trends of satisfying the majority of users and therefore they use more Russian language which was more popular in the past.

However more important is to see the statistics that show how market reacts on behavioral changes of society. Interesting trends are traceable in the results of research of internet audience of Ukraine made by InMind in March 2013. By the results of February 2013 the company determined top 25 domains that are used by Ukrainian users, particular (from 1st to 25 th place in the ranking): Google (average daily share $66 \%$ ), Vkontakte (60\%), Mail.ru (48\%), Yandex (40\%), Odnoklassniki (37\%), Youtube.com (28\%), Wikipedia.org (15\%), Facebook.com (13\%), Ukr.net (12\%), Ex.ua (11\%), I.ua (8\%), Webalta.ru (7\%), Rozetka(.ua+.com.ua) (7\%), Sinoptik.ua (7\%), Rambler.ru (7\%), Aukro.ua (6\%), Gismeteo.ua (6\%), Blogspot.com (6\%), Ucoz.ru (6\%), Rutracker.org (6\%), Fotostrana.ru (5\%), Slando (5\%), Ask.fm (5\%), Marketgid (.com+.info) (5\%), Meta.ua (5\%).

Among these websites there are 8 Ukrainian with domain name that ends on .ua: Ex.ua, I.ua, Rozetka (.ua+.com.ua), Sinoptik.ua, Aukro.ua, Gismeteo.ua, Slando, Meta.ua. [7]

There are two bilingual (Ukrainian-Russian) websites / webmail services among them - Ukr.net та I.ua, two weather forecast websites Sinoptik.ua та Gismeteo.ua, and also online Ukrainian sales board - Slando. Ukrainian web search resource Meta.ua is trilingual (EnglishUkrainian-Russian). At the same time such commercial projects as Ex.ua, Rozetka(.ua+.com.ua), Aukro.ua don't mind to propose Ukrainian language [7]. But in autumn 2016 Rozetka starts the development of Ukrainian version of website and particularly testing it. May be soon we will see full Ukrainian version of the biggest online store of Ukraine [8]. 
According to researches made by S. Svidlovom [9] in 2016 based on data from top.bigmir.net, top.i.ua, liveinternet.ru we can see following statistics: according to top.bigmir.net $13.2 \%$ of websites use Ukrainian language, $28.8 \%$ use two languages, $58 \%$ use Russian languages. According to top.i.ua $28 \%$ of websites use Ukrainian language, $20 \%$ use two languages, $52 \%$ use only Russian language. According to the data of liveinternet.ru Ukrainian language is used on $14 \%$ of websites, there are $24.8 \%$ of websites that are bilingual and $61.2 \%$ use Russian language. If we will compare this research with the results of previous year, we will see that the part of Russian websites in top 250 was reduced by $4.8 \%$.

According to the data of zmiya.com.ua among the most popular users of social networks the part of Ukrainian-speaking users raised by $7 \%$ and now takes first place. Ukrainian-speaking users constitute $49.25 \%$, Russian-speaking - $46.5 \%$, bilingual $-4.25 \%$. According to the information of another website watcher.com the part of Ukrainian users raised only by $3 \%$ up to $43 \%$, the part of Russianspeaking takes $51.75 \%$, bilingual $5.25 \%$ [9].

According to data of Ukrainian manufacturers catalogue "Made in Ukraine" only
$33 \%$ of Ukrainian websites has Ukrainian language. Comparing with previous year the part of websites with Ukrainian language raised only by $1 \%$ in 2015 [9].

According to the data of the research of Razumkov center in 2016 (see Fig. 1), we can see the dynamic of Ukrainian and Russian language use by the population. In the statistic of 2008 we can see the reduction of popularity of Ukrainian language and the raise of the part of bilingual population. The part of Russian language rest almost unchanged so the population only started to use two languages in their life. However the data of 2015 confirm evident changes of those trends. After exacerbation of relations with Russia the part of the population that consider Ukrainian as a native language raised by $16 \%$ up to $59.9 \%$. At the same time the part of bilingual population was not significantly reduced in comparison with the part of population that considered Russian as a native language before. This abrupt change may also be linked to the inability of making research on the Donetsk and Lugansk territories and the absence of information from temporarily occupied Crimea. Despite those facts this statistics will probably appear on the functioning of all spheres of society, including websites [10].

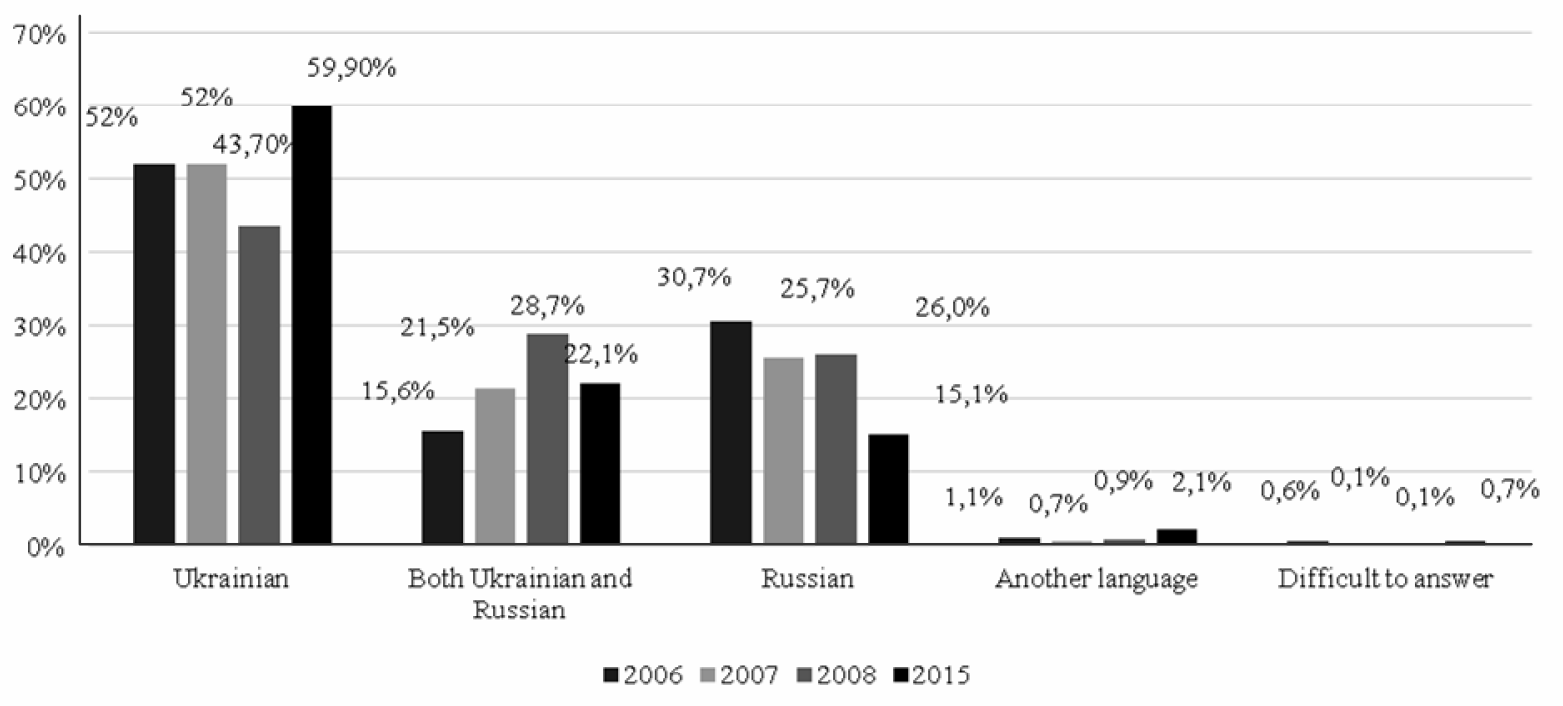

Fig. 1. Statistic of the language perception as a native by the population of Ukraine [10].

There is an interesting statistic shown by [7] about websites of regional administrations in terms of analyze of their websites' languages. Among twenty four regions five websites $(21 \%)$ are bilingual, rather, conditionally bilingual, because the change of language almost always had the problems. One of this websites (Odessa region) promotes interference by publishing the materials 


\section{Ugolkov, O. Karyy}

both on Ukrainian and Russian languages. Nine websites $(38 \%)$ are trilingual, only four of them are fully trilingual, another two are actually bilingual and the rest three are monolingual. And finally one website $(4 \%)$ can be considered as multilingual or monolingual with the possibility to automatically translate pages on one of eighty languages using Google translator [7].

Bold unsolved aspects of the general problem. The issue of multilingualism is extremely important for our society and business. However the question of multiple or single language use on websites is not well researched. This question is often posed not by the scientists but by ordinary users in blogs, forums and other online media. Some data about the use of multiple languages on websites is really outdated and not entirely true due to the change of social and political situation. Today the question of multilingualism requires detailed consideration because the use and refusal of use of Russian or Ukrainian language on websites may cause certain economic consequences.

Purpose and objectives. Purpose of this article is to analyze changes in the linguistic situation on Ukrainian websites of entities that are used for marketing communications with their clients. Main objectives are to make own analysis of current situation of website multilingualism in Ukrainian society and develop the recommendations about the choice of website language.

Main material. If we will look at websites which provide information, we will see that the most important result indicator for them is the quantity of visitors during the period of time. From the point of view of web marketing there are three questions: 1) quality of SEO (search engine optimization); 2) cost of CPC (cost per click) Adwords publicity; 3) content perception of target audience. First point is SEO. The fact that SEO is implemented using publishing of unique content on website with keywords that are used by target audience.

If the website is monolingual so the keywords will be only on Ukrainian that disables SEO using Russia keywords. The same trend is observed in the opposite situation, when we will be using only Russian keywords.

Ukrainian online content is growing, but Russian still prevails. This is the opinion of the director of "Google Ukraine" Dmitry Sholomko. He said: "Google - is only a "mirror" that reflects not only the ratio Ukrainian and Russian content in network, but the language preferences of users" [11]. However, we cannot be fully agreed with his statement, considering next point.

The point we are speaking about is a cost of paid search optimization by Google. The fact is that Google AdWords ranks ads search on a 10-point scale and estimates the cost of ad clicks or ad demonstration based on this scale, existing competition and a number of other factors. These ten points are based on three indicators: 1) the expected CTR (click-through rate) - the more people want to find information on a given keyword - the higher will be our CTR; 2) the relevance of the ad - that means, how much ad matches the keyword that user search; 3) landing page - the quality of a webpage and relativity of information to the keywords searched by user.

The problem is that the last two figures largely depend on the availability of the entered keyword in your ad text and landing page text. Accordingly, if our users are looking for Russian language, the use of the Ukrainian language in the ad or on the webpage/landing page will not allow the system to identify the keywords as those that satisfy the search. As a result, you will pay more money for advertising or you will have to translate your own webpage/landing page on Russian language. If the information will be searched on Ukrainian language - we will pay less for Google advertising is and we will have higher chances of being in top of the advertising list.

Also it's very important to take into account the perception of online content. One of the reasons of Russian language use in Ukrainian Internet is the focus of media resources and strong use of the Internet in the Russian-speaking regions and in Kyiv. I. Mudra [12] provides information about regional distribution of Ukrainian segment of the Internet audience, Kyiv - $66.06 \%$, Odessa $8.49 \%$, Dnepropetrovsk - $7.04 \%$, Donetsk $4.53 \%$, about $15 \%$ are at rest territory. However, these statistics cannot be considered entirely reliable, because most of the traffic is going 
through main servers in Kyiv. We can find interesting statistics in print publications. On 15.10.2012 in Ukraine there were 406 exclusively Ukrainian-language print media, 437 Russian and 325 Ukrainian-Russian print media [13].

O.G. Ruda in her research determined the attitude of population to the duplication of information in two languages. The result is shown in Fig. 2. According to this research $43.2 \%$ approve the use of two languages, $21.7 \%$ don't approve, for $33.5 \%$ it does not matter. This statistic demonstrates for website owners the feasibility to duplicate information in both languages.

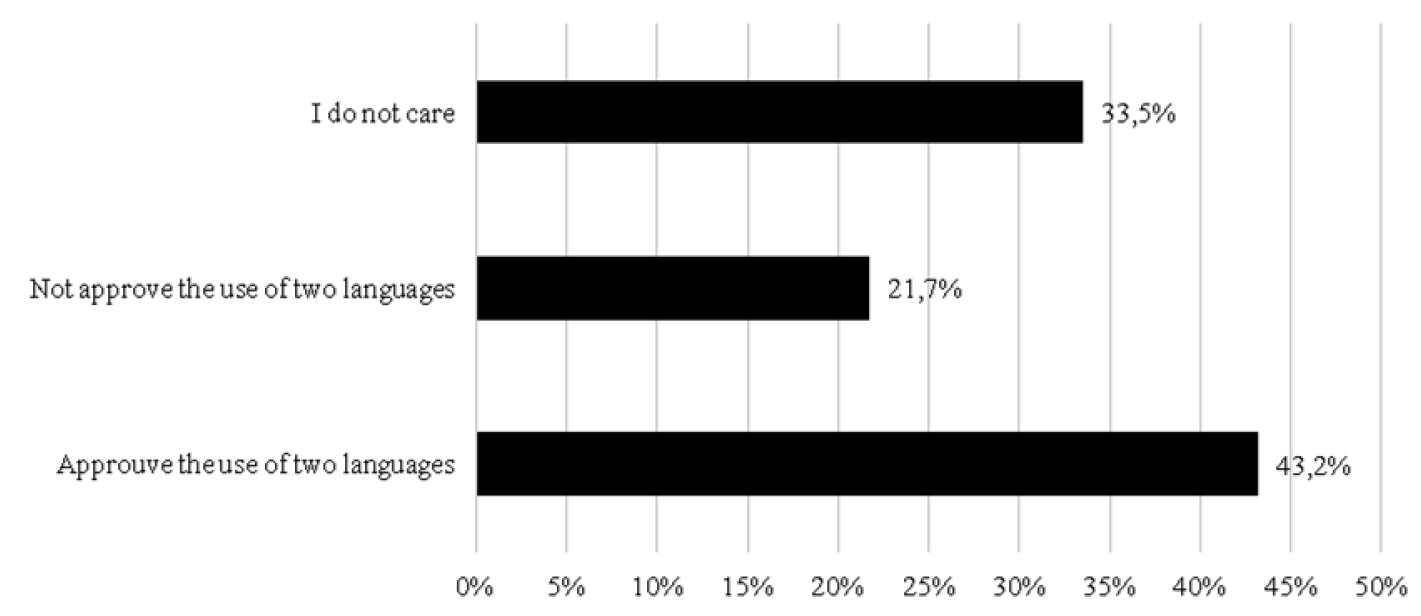

Fig. 2. Attitude to information sources duplicated in Russian and Ukrainian languages [13].

The conflict in the East of the Ukraine in 2014 caused a boycott of Russian goods, which consequently aggravated the language question in business. According to research made by TNS in 2015 more than half of Ukrainian $(58 \%)$ were positive for a boycott of Russian goods, $45 \%$ of respondents personally participated in the boycott. Negative attitude to the boycott had $24 \%$ of Ukrainian - most of them in Eastern and Southern regions. Obviously, in Western Ukraine there are many people who personally participated in the boycott $-71 \%$, next are Kyiv $-61 \%$ and Northern Ukraine $-60 \%$. Interesting is the fact that men $(51 \%)$ are more likely than women $(40 \%)$ boycott Russian products [15]. As a result, the turnover of foreign trade of goods and services between Ukraine and the Russian Federation in the first half of 2015 compared to the first half of 2014 decreased 2.2 times to 7.829 billion dollars [16].

In connection with the above statistics, there are the first consequences for owners of Internet resources. Increased demand for Ukrainian goods and Ukrainian content causes more web searches using Ukrainian language instead of Russian. Thus, the owners of companies that do not optimize their website in Ukrainian language lose users. In addition, as the statistics show, customers refuse to purchase Russian goods. Accordingly, the perception of Russian content in online stores will be negative, that can cause loss of customers, who consider Ukrainian as their native language and this is almost $60 \%$ of the population [10].

After analyzing all the collected data, we decided to conduct our own analysis by examine the use of Ukrainian and Russian language on websites of the 40 strongest banks of Ukraine according to the list of rating portal http://minfin.com.ua [17] and http://www.forinsurer.com [18]. Observations was made by surfing online and analyzing websites of this banks. Bank sector was chosen because it is enough well developed in Ukraine and is the most heavily impacted by customer confidence to cooperate with them and the most responsive to their consumer behavior. It should be noted that the data could have an impact from certain banks "regionalism". For example, some banks are active in Western Ukraine and other are focused on Eastern and Southern Ukraine. That is why we have used bank ratings that provide statistics from all regions and minimize error. Observations was made on 12 January 2017 by Ievgenii Ugolkov and 


\section{Ugolkov, O. Karyy}

Oleg Karyy from the department of management of organizations, Lviv Polytechnic National University. Below you will find an analysis of the information that we collected.

First question that we posed in our research was about the languages that are used on websites of Ukrainian banks. The results are shown on the Fig. 3. As we can see the most popular is the use of three languages together (Ukrainian, Russian, English). Three languages are used by twenty three of forty banks, representing $57.5 \%$. Eight from forty banks use Ukrainian and Russian language that is $20 \%$. There are four banks that use only Ukrainian language, representing $10 \%$. Only Russian language is used by one bank that makes $2.5 \%$. Other languages were not represented on the websites of the analyzed banks indicating the refusal of their use. Even the foreign banks as Polish KredoBank and French UkrSibBank don't use the language of their countries of origin.
Second question that be posed in this research was the choice of the default language on the websites of Ukrainian banks. The results are shown of the Fig. 4. Despite the fact that only the Russian language in used on the website of one bank Ukraine, we have 5 banks that use Russian as a default language, representing $12.5 \%$. Other 35 banks $(87.5 \%)$ use the Ukrainian language as a default. English is not used as a default language on the websites of Ukrainian banks.

It is important to mention that the use of multiple languages often leads the low quality of one or two of them. Banks that are using Ukrainian language as a main often have poor quality Russian or English versions. To economize the time they don't translate the articles, banners, news and promotions on other languages. In addition, we can find limited functionality in these versions (for example Internet banking).

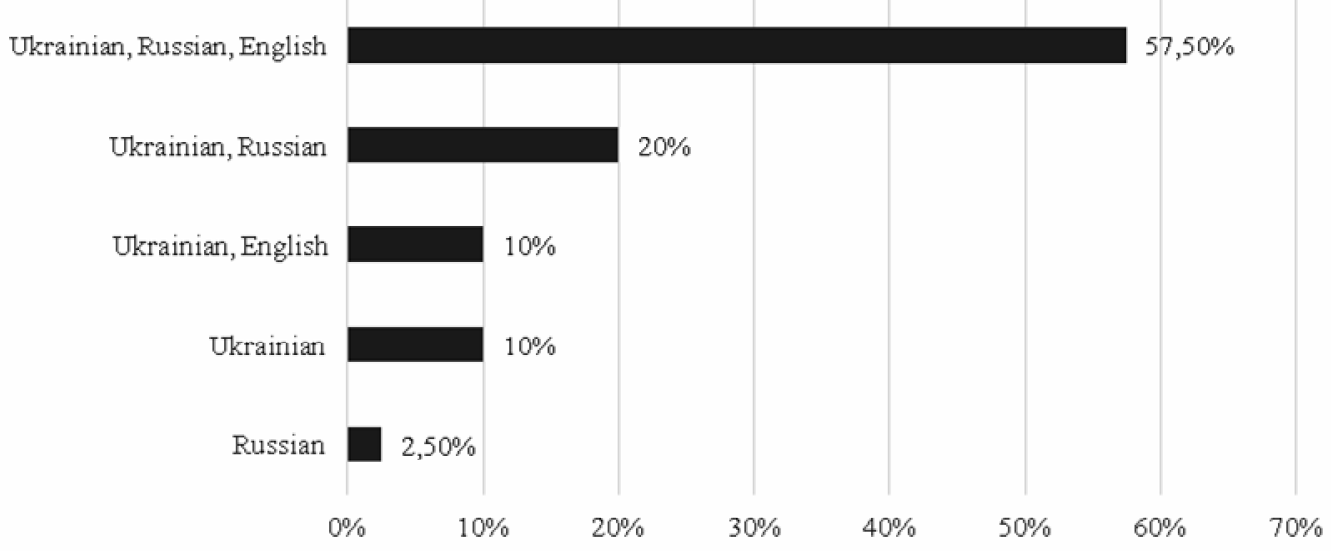

Fig. 3. Languages that are used on the websites of Ukrainian banks.

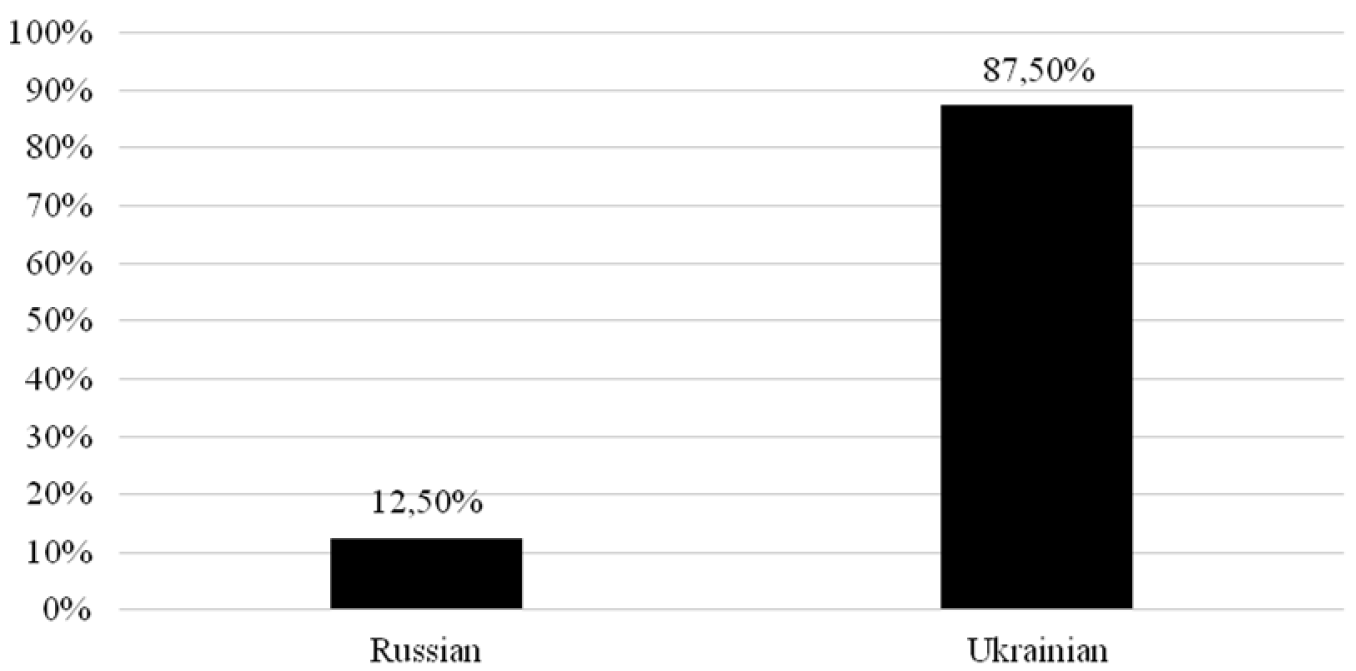

Fig. 4. Language set as default on the websites of Ukrainian banks. 
On the basis of the analyses of the languages use on the websites of Ukrainian banks we can confidently say that they are oriented on the maximum satisfaction of modern need of Ukrainian client. Most of them use three languages on their websites: Ukrainian, often as a default, to minimize the risks of losing the client that enters website, Russian to satisfy another part of Russian speaking population, and English that enables to make certain international activity and slightly improve the reputation of bank in the eyes of potential client. Only Russian or only Ukrainian languages are used infrequently.

\section{Conclusion and directions for further} researches. After analyzing the literature, previous statistics and conducting our own analysis it is safe to say that at the moment we cannot still talk about total inclusiveness of Ukrainian language in everyday life or in business. The big part of population continues to use Russian when they are searching and buying goods and don't pay attention to political and social factors. Therefore, a complete rejection of the Russian-language content is currently not feasible. Even for Internet resources that narrowly focused on the western regions, the lack of Russian-language content may adversely affect the attraction of users.

Therefore, the best solution for quality promotion of websites currently demands the multilingualism. Moreover, in a period of a conflict it is important to use Ukrainian language as default and Russian as a minor for the purpose of avoiding negative perceptions of the Ukrainian and Russianspeaking users. This strategy allows achieving maximum effect from search engine optimization and minimizing the risk of refuses of users on websites.

On the other hand, companies need constantly to monitor public attitudes of the use of languages because they are dynamically changing. This will reduce the potential user dissatisfaction and effectively engage them to interact.

\section{References}

1. Pravo na ukrajinomovnyj prostir. [The right to a Ukrainian language space]. (2015). Retrieved from // http://language-policy.info/2015/02/pravo-naukrajinomovnyj-prostir/ (refered on 24.03.2017). [in Ukrainian].
2. V Ukraini dvomovnist ye asymetrychnoiu, na vidminu vid sytuatsii v kolyshnii Chekhoslovachchyni. [In Ukraine bilingualism is asymmetric, unlike the situation in Czechoslovakia]. (2016). Retrieved from // http://www.radiosvoboda.org/content/ articlel 27416529.html (refered on 24.03.2017). [in Ukrainian].

3. Yevstratova, S. (2012). The use of Russian in the media of Estonia, Journal "Slovo.ru: Baltijskij accent”, no. 2, p. 44-48. [in Russian].

4. Mechkovskaya, N, (2011). Post-Soviet languages in conditions of state sovereignty and flourishing of information technologies, Journal the Belarusian State University, Vol. 4, no. 2, p. 75-82. [in Russian].

5. Miller, R. (1984). 5 response of business firms to francization process, Conflict and language planning in Quebec, Clevedon, Avon, England : Multilingual Matters, p. 114-130.

6. Uspadkovana dyskryminatsiia: nosii ukrainskoi movy prodovzhuiut zaznavaty utyskiv u vlasnii derzhavi [Inherited discrimination: Ukrainian language speakers continue to suffer oppression in their own country 2012]. (2012). Retrieved from // http://tyzhden.ua/Politics/51271 (refered on 24.03.2017). [in Ukrainian].

7. Ponomarenko, L. (2014). The language of websites of Ukrainian segment of Internet: realities and prospects, Journal "The state and the regions" Series: Humanities, no 1-2 (36-37), p. 64-69. [in Ukrainian].

8. Rozetka testuie ukrainsku versiiu saitu [Rozetka test Ukrainian version of website]. (2016). Retrieved from // http://watcher.com.ua/2016/ 10/27/rozetka-testuye-ukrayinsku-versiyu-saytu/ (refered on 24.03.2017) [in Ukrainian].

9. Stanovyshche ukrainskoi movy $v$ ukrainskomu sehmenti internetu. [The position of the Ukrainian language in the Ukrainian segment of the Internet 2016].(2016). Retrieved from // http://languagepolicy.info/2016/10/stanovysche-ukrajinskojimovy-v-ukrajinskomu-sehmenti-internetul (refered on 24.03.2017) [in Ukrainian].

10. Konsolidatsiia ukrainskoho suspilstva: shliakhy, vyklyky, perspektyvy [The identity of the citizens of Ukraine in the new environment: state, trends and regional differences]. (2016). Razumkov center, Informatsiino-analitychni materialy do fakhovoi dyskusii, 20-25. Retrieved from http:/lold. razumkov. org.ua/upload/Identi-2016.pdf . [in Ukrainian].

11. Dyrektor Google Ukraina poiasnyv, shcho treba robyty, aby u poshukovyku ziavlialosia bilshe kontentu ukrainskoiu [Director of Google Ukraine explained what to do to make appear more 


\section{Ugolkov, O. Karyy}

Ukrainian content in search engines]. (2016).

Retrieved from //http://language-policy.info/2016/ 09/dyrektor-google-ukrajina-poyasnyv-scho-trebarobyty-aby-u-poshukovyku-z-yavlyalosya-bilshekontentu-ukrajinskoyu/ (refered on 24.03.2017) [in Ukrainian].

12. Mudra, I. (2013). Language as a tool of marketing in press. Journal of Taras Shevchenko National University of Kyiv [Journal of Taras Shevchenko National University of Kyiv], no 14, p. 102-107. [in Ukrainian].

13. Ruda, O. G. (2014). Bilingualism of the media in estimates of future journalists. Ukrainian language: scientific and theoretical journal of Institute of Ukrainian language of National academy of science of Ukraine, no 3, p. 84-92. [in Ukrainian].

14. Ukraintsi perekhotily druhu derzhavnu. [Ukrainians don't wont second state language 2011] (2011). Retrieved from http://www.pravda. com.ua/news/ 2011/09/7/6567769/ // http://www.pravda. com.ua/news/2011/09/7/6567769/ (refered on 24.03.2017) [in Ukrainian].
15. Shcho dumaiut ukraintsi pro vbyvstvo Borysa Niemtsova $i$ boikot rosiiskykh tovariv? [What Ukrainians think about the murder of Borice Nemcov and boycott of Russian products?]. (2015). Retrieved from https://tns-ua.com/news/chtodumayut-ukraintsyi-ob-ubiystve-borisa-nemtsova- $i$ boykote-russkih-tovarov[in Ukrainian].

16. Ukraina skorotyla obsiah torhivli z Rosiieiu v 2,2 razy. [Ukraine reduced the volume of trade with Russian in 2,2 times]. (2015). Retrieved from http://www.epravda.com.ua/news/2015/10/2/56194 5/ [in Ukrainian].

17. Reitynh ustoichyvosty bankov po ytoham 3 kvartala 2016. [The rating of banks stability by the results of Q3 2016]. (2016). Retrieved from http://minfin.com.ua/banks/rating/// http://minfin.com.ua/banks/rating/ (refered on 24.03.2017) [in Russian].

18. Reitynh bankov Ukraynbl za 9 mesiatsev 2016. [The rating of Ukrainian banks for 9 monthes of 2016].(2016). Retrieved from http://forinsurer. com/ratings/banks/16/9/3 (refered on 24.03.2017) [in Russian]. 